\title{
12/15-lipoxygenase orchestrates the clearance of apoptotic cells and maintains immunologic tolerance
}

\author{
Stefan Uderhardt ${ }^{1}$, Martin Herrmann ${ }^{1}$, Olga Oskolkova ${ }^{2}$, Reinhard Voll ${ }^{1}$, Falk Nimmerjahn ${ }^{3}$, Valery Bochkov², \\ Georg Schett ${ }^{1}$, Gerhard Kroenke ${ }^{1 *}$
}

From 6th European Workshop on Immune-Mediated Inflammatory Diseases

Nice, France. 23-25 November 2011

The coordinated and non-inflammatory phagocytosis of apoptotic cells is crucial to maintain immunological tolerance. During inflammation, however, ingestion of apoptotic material by inflammatory phagocytes can provoke a break in self-tolerance. Hence, and though poorly understood, mechanisms governing the sorting of apoptotic cells into distinct and differentially-activated subsets of phagocytes are essential to prevent autoimmunity.

Here we identify the enzyme 12/15-lipoxygenase (12/ 15-LO) as a crucial factor orchestrating the clearance of apoptotic cells under inflammatory conditions. During peritonitis, the ingestion of apoptotic cells is confined to a distinct population of alternatively-activated, 12/15LO-expressing resident macrophages (resMФ). Deletion of $12 / 15$ - LO changed this pattern and neighbouring inflammatory macrophages (infM $\Phi$ ) start to engulf apoptotic cells.

We hypothesized that resM $\Phi$ exert a paracrine and 12/ 15-LO-mediated inhibitory activity on the phagocytic capacity of infM $\Phi$ and identified oxidation products of phosphatidyl ethanolamine (oxPE) as the corresponding mediators. oxPE is generated by the action of $12 / 15$-LO in $\operatorname{res} M \Phi$ and consequently exposed on the macrophages' surfaces. Here, oxPE binds, blocks and scavenges soluble MFG-E8 protein and thereby selectively blocks the major pathway involved in the uptake of apoptotic cells into infMФ. In turn, we observed a break in self-tolerance and lupus-like autoimmune disease in aged 12/ 15-LO-deficient mice. These mice displayed spontaneous production of autoantibodies and glomerulonephritis,

${ }^{1}$ Internal Medicine 3, University of Erlangen, Germany

Full list of author information is available at the end of the article which both exacerbated after apoptotic challenge in the pristane-induced model of experimental murine lupus.

Our data point towards a so far unrecognized role for enzymatic lipid oxidation during the maintenance of selftolerance and identify a mechanism, which orchestrates the cell- and context-specific uptake of antigens by different subsets of phagocytes, imposing a new paradigm in our understanding of the clearance of apoptotic cells.

\section{Author details}

'Internal Medicine 3, University of Erlangen, Germany. ${ }^{2}$ Vascular Biology, Medical University of Vienna, Vienna, Austria. ${ }^{3}$ Dept. of Genetics, University of Erlangen, Germany.

Published: 23 November 2011

\section{doi:10.1186/1479-5876-9-S2-P5}

Cite this article as: Uderhardt et al:: 12/15-lipoxygenase orchestrates the clearance of apoptotic cells and maintains immunologic tolerance. Journal of Translational Medicine 2011 9(Suppl 2):P5.

Submit your next manuscript to BioMed Central and take full advantage of:

- Convenient online submission

- Thorough peer review

- No space constraints or color figure charges

- Immediate publication on acceptance

- Inclusion in PubMed, CAS, Scopus and Google Scholar

- Research which is freely available for redistribution 